\title{
Liver fibrosis secondary to bile duct injury: correlation of Smad7 with TGF- $\beta$ and extracellular matrix proteins
}

María del Pilar Alatorre-Carranza1 ${ }^{1}$, Alejandra Miranda-Díaz ${ }^{1}$, Irinea

Yañez-Sánchez ${ }^{1}$, Oscar Pizano-Martínez ${ }^{1}$, José M Hermosillo-Sandoval ${ }^{2}$, Mónica Vázquez-Del Mercado3,5, Sebastián Hernández-Hoyos², Ricardo Martínez-Abundis ${ }^{2}$, Mary Fafutis-Morris ${ }^{1}$, Jorge Segura-Ortega ${ }^{4}$ and Vidal Delgado-Rizo*1

Address: ${ }^{1}$ Departamento de Fisiología, Centro Universitario de Ciencias de la Salud, Universidad de Guadalajara; Sierra Mojada 950, Col. Independencia, Guadalajara, Jalisco 44340 México, ${ }^{2}$ Hospital de Especialidades Centro Médico Nacional de Occidente, IMSS; Belisario Domínguez 1000, Col. Independencia, Guadalajara, Jalisco 44340 México, ${ }^{3}$ Instituto de Investigación en Reumatología y Sistema Músculo Esquelético (IIRSME), Universidad de Guadalajara; Sierra Mojada 950, Col. Independencia, Guadalajara, Jalisco 44340 México, ${ }^{4}$ Servicio de Gastroenterología Hospital Civil de Guadalajara, Universidad de Guadalajara, Hospital 278, Col. El Retiro, Guadalajara, Jalisco 44280 México and ${ }^{5}$ Departamento de Reumatología, Hospital Civil de Guadalajara "Dr. Juan I. Menchaca", Universidad de Guadalajara, Salvador Quevedo y Zubieta 750, Col. Independencia, Guadalajara, Jalisco 44340 México

Email: María del Pilar Alatorre-Carranza - pilyac@hotmail.com; Alejandra Miranda-Díaz - alexmiranda1@hotmail.com; Irinea Yañez-Sánchez - irisys70@hotmail.com; Oscar Pizano-Martínez - sorrento80@hotmail.com;

José M Hermosillo-Sandoval - dr_jmhermosillo@hotmail.com; Mónica Vázquez-Del Mercado - dravme@hotmail.com; Sebastián Hernández-Hoyos - dr_sebastianhh@yahoo.com; Ricardo Martínez-Abundis - dr_abundismtz@hotmail.com;

Mary Fafutis-Morris - mfafutis@gmail.com; Jorge Segura-Ortega - jorsegura10@yahoo.com.mx; Vidal Delgado-Rizo* - vidal@cencar.udg.mx

* Corresponding author

Published: 31 October 2009

BMC Gastroenterology 2009, 9:81 doi:10.1 186/1471-230X-9-81

This article is available from: http://www.biomedcentral.com/I47/-230X/9/8 I

(C) 2009 del Pilar Alatorre-Carranza et al; licensee BioMed Central Ltd.

This is an Open Access article distributed under the terms of the Creative Commons Attribution License (http://creativecommons.org/licenses/by/2.0), which permits unrestricted use, distribution, and reproduction in any medium, provided the original work is properly cited.

\begin{abstract}
Background: Liver fibrosis is the result of continuous liver injury stemming from different etiological factors. Bile duct injury induces an altered expression of TGF- $\beta$, which has an important role in liver fibrosis because this cytokine induces the expression of target genes such as collagens, PAI-I, TIMPs, and others that lead to extracellular matrix deposition. Smad7 is the principal inhibitor that regulates the target gene transcription of the TGF- $\beta$ signaling. The aim of the study was to determine whether Smad7 mRNA expression correlates with the gene expression of TGF- $\beta$, Col I, Col III, Col IV, or PAI-I in liver fibrosis secondary to bile duct injury (BDI).

Results: Serum TGF- $\beta$ concentration was higher in BDI patients $(39296 \mathrm{pg} / \mathrm{ml})$ than in liver donors $(9008 \mathrm{pg} /$ $\mathrm{ml}$ ). Morphometric analysis of liver sections showed $41.85 \%$ of tissue contained fibrotic deposits in BDI patients. mRNA expression of Smad7, Col I, and PAI-I was also significantly higher $(P<0.05)$ in patients with BDI than in controls. Smad7 mRNA expression correlated significantly with TGF- $\beta$ concentration, Col I and Col III expression, and the amount of fibrosis.

Conclusion: We found augmented serum concentration of TGF- $\beta$ and an increase in the percentage of fibrotic tissue in the liver of BDI patients. Contrary to expected results, the 6-fold increase in Smad7 expression did not inhibit the expression of TGF- $\beta$, collagens, and PAI-I. We also observed greater expression of Col I and Col III mRNA in BDI patients and significant correlations between their expression and TGF- $\beta$ concentration and Smad7 mRNA expression.
\end{abstract}




\section{Background}

Liver fibrosis is caused mainly by alcohol consumption and viral hepatitis, and it is an important health problem throughout the world. Bile duct injury (BDI) is also an important etiological factor because it can cause secondary biliary cirrhosis and long-term disability, and it increases the risk of death threefold[1,2]. BDI can occur as a complication of cholecystectomy, an elective surgery for cholelithiasis. The introduction of laparoscopy has increased the BDI incidence to $0.3-1.0 \%$, which is higher than that associated with open cholecystectomy (0.1$0.3 \%)$ [3-5].

BDI causes obstruction of bile ducts, which results in cholestasis. BDI increases the concentrations of serum aminotransferases, bilirubin, and alkaline phosphatase (AP). As the obstruction proceeds, the accumulation of biliary salts in the canalicular membrane produces dilatation of bile ducts, which may rupture and form bile deposits. Mononuclear cells infiltrate into the portal tracts and bile ducts proliferate, leading to degeneration of hepatocytes and periportal fibrosis deposition[3,6-8].

Transforming growth factor- $\beta$ (TGF- $\beta$ ) is a multifunctional cytokine involved in the regulation of cell proliferation, differentiation, extracellular matrix (ECM) production, wound healing, and tissue repair. TGF- $\beta$ plays an important role in liver fibrogenesis because it triggers the overexpression and deposition in the ECM of molecules such as PAI-1, TIMP-1, Col I, Col III, Col IV, tenascin, fibronectin, and Smad7 [9-14].

Smad7 is the principal inhibitor that regulates the target gene transcription of the TGF- $\beta$ signaling $[15,16]$. Smad7 exerts its inhibitory effect by its association with activated TGF- $\beta$ I receptor and inhibition of Smad2/3 phosphorylation.

Smad7 has been used in experimental models to block TGF- $\beta$ effects in different disorders [17-19]. Dooley et al[20] and Tahashi et al[16] demonstrated that Smad7 expression was low in experimental liver fibrosis, and this event allows liver scar formation. Some investigators have used gene therapy $[16,20,21]$ with an adenoviral vector containing Smad7 complementary DNA (cDNA) and a Chinese herbal medicine[22], to treat fibrosis and cirrhosis in different experimental models. However, there are no reports on Smad7 in human liver fibrosis. In this context, the aim of our study was to determine whether Smad7 mRNA expression correlates with the expression of TGF- $\beta$, Col I, Col III, Col IV, and PAI-1 genes in BDI patients and to compare these relationships with controls (liver donors).

\section{Methods \\ Patients and samples}

Eighteen patients were included in this study. Fourteen patients had extrahepatic BDI caused by open or laparoscopic cholecystectomy that had been reconstructed surgically. These patients were recruited from Centro Médico General de Occidente, and 4 liver donors with normal liver histology, recruited from the Hospital Civil de Guadalajara, were included as a control group. The serum concentrations of alanine aminotransferase (ALT), aspartate aminotransferase (AST), direct bilirubin (DB), and AP were measured before the reconstruction surgery. Serum was obtained from a peripheral blood (PB) sample without anticoagulant from each patient and control. Liver biopsy specimens were obtained during bile duct reconstruction surgery. None of the patients or controls had a clinical history of previous liver disease or alcohol or drug abuse. The study protocol was in accordance to the ethical guidelines of the World Medical Association Declaration of Helsinki (adopted by the 52nd WMA General Assembly, Edinburgh, Scotland, October 2000) and was approved by the ethical committee of the institutions. Informed written consent was obtained from each patient and control.

\section{Histological analysis}

The liver specimens were fixed immediately in 4\% paraformaldehyde solution, buffered to $\mathrm{pH} 7.4$, and embedded in paraffin. Five-micrometer sections were cut and stained with Masson's trichrome. The proportion of each field displaying fibrosis was analyzed using computer image analysis software (Image Pro Plus 4.0). Briefly, regions of the section with the optical density characteristics of fibrosis where counted and analyzed as a percentage of the total tissue. The total collagen surface density was measured in 20 random fields at a magnification of $20 \times$ and is expressed as the percentage of total section area.

\section{ELISA for TGF- $\beta$}

An ELISA kit (R\&D Systems) was used to measure the serum concentration of TGF- $\beta$ following the manufacturer's protocol. The samples were activated by adding $200 \mu \mathrm{l}$ in a tube with $200 \mu \mathrm{l}$ of $2.5 \mathrm{M}$ acetic acid, mixed, incubated for $10 \mathrm{~min}$ at room temperature, and inactivated with $200 \mu \mathrm{l}$ of $2.7 \mathrm{M} \mathrm{NaOH}$ in $1 \mathrm{M}$ HEPES. One hundred microliters of the activated sample, negative control, and the standards were added to the plate in triplicate. The absorbance was measured at $450 \mathrm{~nm}$.

\section{RNA extraction}

Total RNA was extracted from a section of each liver biopsy using Trizol (Invitrogen ${ }^{\mathrm{TM}}$ ) according to the manufacturer's instructions. The tissue was homogenized with 
$500 \mu \mathrm{l}$ of Trizol. Chloroform (Sigma) was added and the sample was centrifuged at $10,000 \mathrm{rpm}$ at $4^{\circ} \mathrm{C}$. The total RNA was precipitated with isopropanol (Sigma). The RNA pellet was washed with 75\% ethanol and dissolved in diethylene pyrocarbonate (DEPC) water. The final concentration and quality of RNA were determined by spectrophotometry, and the absorbance was measured at 260 and $280 \mathrm{~nm}$.

\section{Reverse transcription and real-time Polymerase chain reaction (PCR)}

Total RNA was reverse transcribed to cDNA using SuperScript III (Invitrogen ${ }^{\mathrm{TM}}$ ) enzyme. Two hundred nanograms of total RNA, $1 \mu \mathrm{l}$ of $10 \mathrm{mM}$ dNTP mix, $1 \mu \mathrm{l}$ of $(0.125 \mu \mathrm{g} /$ $\mu \mathrm{l})$ random primers, and DEPC water up to $13 \mu \mathrm{l}$ were incubated at $70^{\circ} \mathrm{C}$ for $5 \mathrm{~min}$. Four microliters of $5 \times$ firststrand buffer, $1 \mu \mathrm{l}$ of $0.1 \mathrm{M}$ DTT, $1 \mu \mathrm{l}$ of RNaseOUT, and $1 \mu \mathrm{l}$ of SuperScript III were added, and the samples were incubated at $25^{\circ} \mathrm{C}$ for $5 \mathrm{~min}$ (annealing), at $50^{\circ} \mathrm{C}$ for 50 min (cDNA synthesis), and at $72^{\circ} \mathrm{C}$ for 15 min (enzyme denaturation).

Real-time PCR was performed with an ABI Prism 7500 Sequence Detection System (Applied Biosystems). Two microliters of cDNA was used in each PCR reaction. The housekeeping gene 18S rRNA (Applied Biosystems) was used for normalization and water was used as a no-template control. The primers and probes (Applied Biosystems) for the PCR reaction were those for the target genes TGF- $\beta$, Col I, Col III, Col IV, PAI-1, and Smad7 (Table 1).

Each sample was analyzed in triplicate. Two microliters of each cDNA sample was mixed with $7 \mu$ l of DEPC water, 10 $\mu \mathrm{l}$ of Universal Master Mix (Applied Biosystems), and $1 \mu \mathrm{l}$ of primer and probe (Applied Biosystems) of either the housekeeping or the target gene. Twenty microliters of this mixture was added to each well for each sample.

The relative quantification was calculated using the $\Delta \Delta \mathrm{C}_{\mathrm{T}}$ method. The mean $\mathrm{C}_{\mathrm{T}}$ of triplicate samples was used to calculate the $\Delta \mathrm{C}_{\mathrm{T}}$ as the difference in $\mathrm{C}_{\mathrm{T}}$ between the target and reference gene. $\Delta \mathrm{C}_{\mathrm{T}}$ for each sample minus the experimental reference $\Delta \mathrm{C}_{\mathrm{T}}$ control was expressed as the $\Delta \Delta \mathrm{C}_{\mathrm{T}}$.
The relative quantification is expressed as the fold expression of the target gene compared with the reference control expression according to the formula $2^{-\Delta \Delta C T}$ and expressed in relative expression units (REU).

\section{Statistics}

The results are expressed as mean \pm SD. Student's $t$ test was used to analyze differences between groups, and the Spearman $\left(\mathrm{r}_{\mathrm{s}}\right)$ correlation was used to analyze relationships between variables. $P$ values $<0.05$ were considered significant.

\section{Results}

\section{Biochemical studies}

The 14 BDI patients ( 10 women and 4 men) had a mean age of 43.9 years (range, 17-65 years), and the 4 controls (liver donors) had a mean age of 37.2 years (range, 21-61 years). The BDI patients had higher concentrations of the aminotransferases, DB, and AP (Table 2).

\section{Bismuth classification}

According to the Bismuth classification method for iatrogenic BDI[23], 11 patients were classified with lesion type 3 , 2 with lesion type 2 , and 1 with lesion type 1 (Table 2 ). The lesion type did not correlate with the mRNA expression, with the extent of fibrosis, or serum TGF- $\beta$ concentration. Further experiments, with a larger patient group, will be necessary to prove if the type or severity of BDI does or does not influence the liver fibrosis process.

\section{Liver fibrosis}

Liver biopsies stained with Masson's trichrome stain showed significant collagen levels in BDI patients (Figure 1B) we correlated collagen levels with increases in fibrosis. Less of the ECM was stained in the livers of the controls (Figure 1A). The morphometric analysis was correlated with an average of $41.85 \%$ fibrosis in the BDI group compared with $0.83 \%$ fibrosis in the control group $(P=0.001)$ (Figure 2). The increase in collagen staining did not correlate with the lesion type in the BDI patient group, probably because of the variety of types in these patients. In the morphological examination of liver biopsies from patients, we observed cholestasis, fibrosis around portal

Table I: Primers and probes of the genes studied

\begin{tabular}{|c|c|c|c|}
\hline Gene & $\begin{array}{l}\text { GenBank } \\
\text { (Accession number) }\end{array}$ & Applied Biosystems ID & Dye \\
\hline I8S rRNA & -- & FG I8S RNA & VIC \\
\hline TGF- $\beta$ & NM000660 & HSO0I7I257_ml & FAM \\
\hline Coll & NM000089 & Hs00164099_ml & FAM \\
\hline Col III & NM000090 & Hs00I64I03_ml & FAM \\
\hline Col IV & NM 001845 & $\mathrm{Hs} 00266237 \_\mathrm{ml}$ & FAM \\
\hline PAl-I & NM 000602 & $\mathrm{Hs} 00 \mathrm{I} 67155 \_\mathrm{ml}$ & FAM \\
\hline Smad7 & NM005904 & Hs00I78696_ml & FAM \\
\hline
\end{tabular}


Table 2: Clinical and biochemical features of control and bile duct injury (BDI) patients groups

\begin{tabular}{|c|c|c|c|c|c|c|c|}
\hline Group & $\mathbf{N}$ & Bismuth (lesion type) & Time post-lesion (days) & $\begin{array}{r}\text { ALT } \\
(0-45 \text { UI/I) }\end{array}$ & $\begin{array}{r}\text { AST } \\
(0-4 \mid \text { UI/I) }\end{array}$ & $\begin{array}{r}D B \\
(0.1-0.4 \mathrm{mg} / \mathrm{dl})\end{array}$ & $\begin{array}{r}\text { AP } \\
(30-115 \text { UI/I) }\end{array}$ \\
\hline \multirow[t]{4}{*}{ Control } & 1 & $0+$ & 0 & 16 & 18 & 0.36 & 21 \\
\hline & 2 & $0 \dagger$ & 0 & 5 & 6 & 0.29 & 68 \\
\hline & 3 & $0+$ & 0 & 26 & 23 & 0.43 & 73 \\
\hline & 4 & $0+$ & 0 & 12 & 19 & 0.12 & 49 \\
\hline BDI & 1 & 2 & 49 & 265 & 110 & 3.70 & 380 \\
\hline \multirow[t]{13}{*}{ patients } & 2 & 1 & 2190 & 365 & 479 & 3.70 & 740 \\
\hline & 3 & 3 & 49 & 133 & 127 & 0.20 & 391 \\
\hline & 4 & 3 & 489 & 54 & 58 & 5.10 & 284 \\
\hline & 5 & 3 & 43 & 132 & 98 & 5.10 & 114 \\
\hline & 6 & 3 & 56 & 197 & 79 & 0.90 & 378 \\
\hline & 7 & 3 & NA & 273 & 22 & 2.80 & 899 \\
\hline & 8 & 2 & 145 & 133 & 58 & 2.90 & 860 \\
\hline & 9 & 3 & 65 & 164 & 168 & 2.00 & 357 \\
\hline & 10 & 3 & 70 & 338 & 40 & .01 & 489 \\
\hline & 11 & 3 & 42 & 285 & 85 & 6.20 & 806 \\
\hline & 12 & 3 & 1 & 106 & 95 & 23 & 320 \\
\hline & 13 & 3 & 1825 & 140 & NA & 0.90 & 306 \\
\hline & 14 & 3 & 56 & 222 & 117 & NA & 296 \\
\hline
\end{tabular}

$t=$ without lesion

$\mathrm{NA}=$ not available

triad, proliferation of bile ducts and periportal inflammatory infiltrate.

\section{Serum TGF- $\beta$ concentration}

TGF- $\beta$ concentration was measured in the PB of only 9 of the 14 BDI patients because it was not possible to obtain blood samples from all patients. Serum TGF- $\beta$ concentration was significantly higher in the patients than in the controls (Figure 3). The mean concentrations were 39296 $\mathrm{pg} / \mathrm{ml}$ (range, 15 565-65 $194 \mathrm{pg} / \mathrm{ml}$ ) in patients and 9008 $\mathrm{pg} / \mathrm{ml}$ (range, 2622-20 $880 \mathrm{pg} / \mathrm{ml})$ in controls $(P=$ $0.005)$.

\section{TGF- $\beta$, Smad7, Col I, Col III, Col IV, and PAI-I gene expression}

To evaluate the differential gene expression, we quantified the level of TGF- $\beta$ mRNA expression and its target genes, Smad7, Col I, Col III, Col IV, and PAI-1 in both groups. The mean TGF- $\beta$ mRNA level was 11 -fold higher in BDI patients (11.59 REU) than in the controls (liver donors)
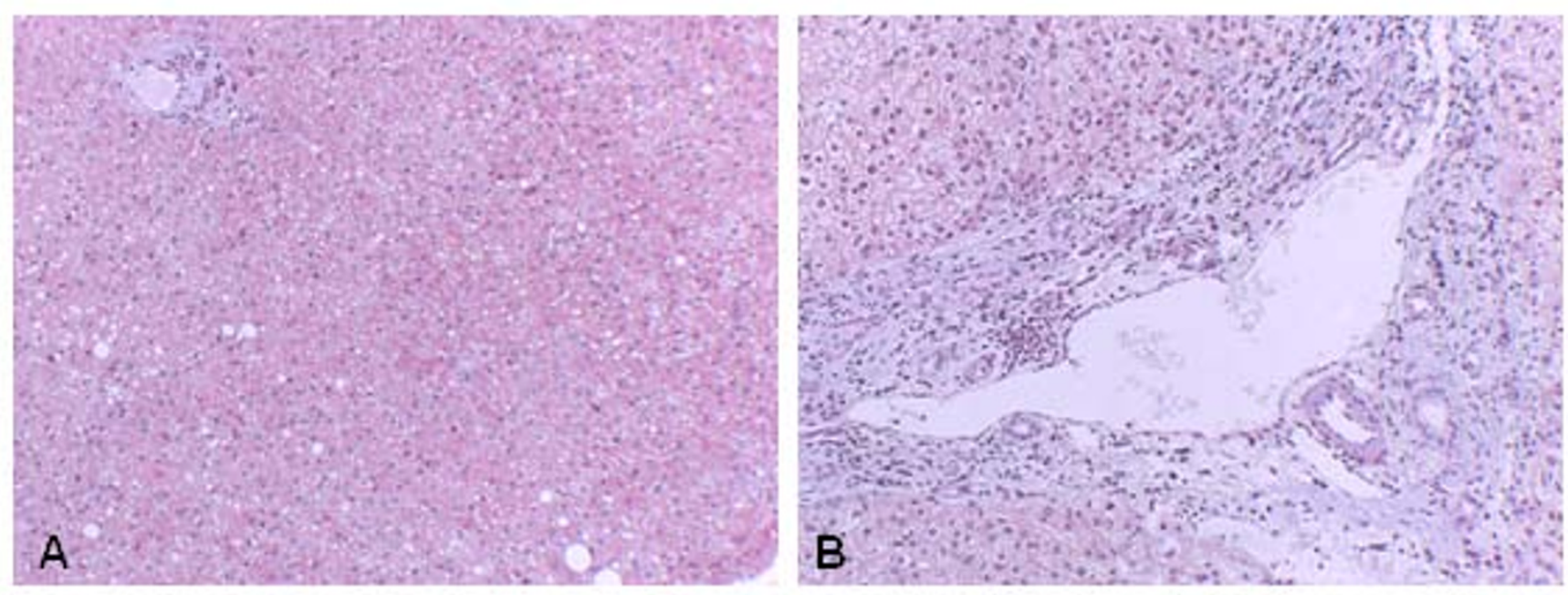

Figure I

Liver fibrosis. The liver section stained with Masson's trichrome from a control (A), compared with a BDI patient (B) showed significant deposition of ECM proteins (blue stain) in B. 


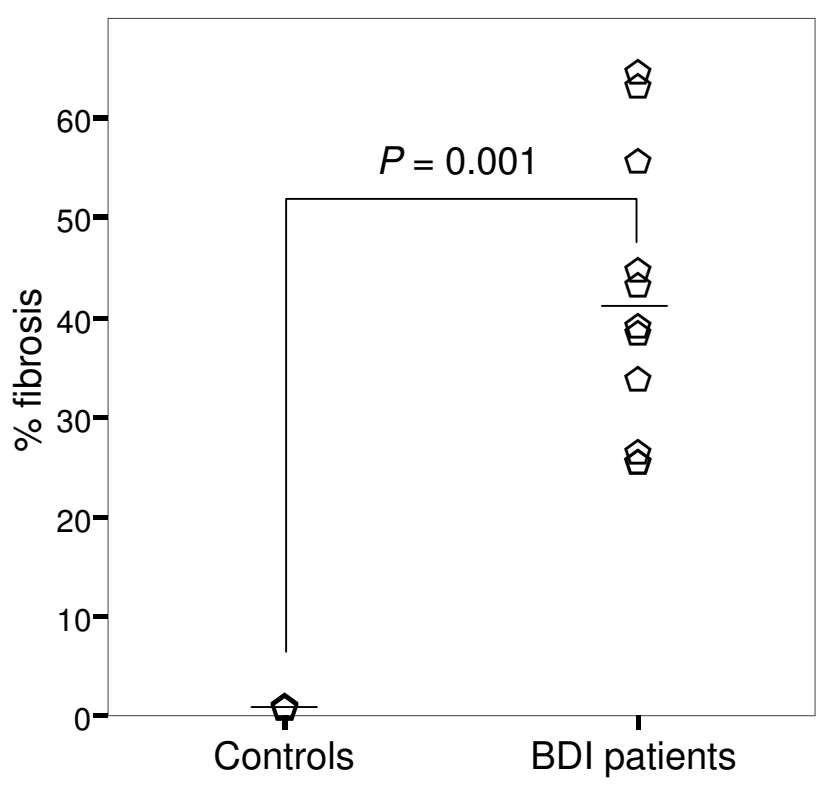

Figure 2

Percent optical density of collagen staining. Morphometric analysis demonstrates more fibrosis in a liver section from BDI patients, who had an average of $41.85 \%$ fibrosis in liver tissue, which differed significantly from the percentage in the control group.

$(P=0.138)$ (Figure 4A). Smad7 mRNA expression showed a similar pattern: 6.69 REU in patients and 1.12 REU in controls $(P=0.005)$ (Figure $4 \mathrm{~B})$.

Collagen mRNA expression was higher in the BDI group. The mean level of Col I mRNA was 26.86 REU in patients and 1.35 REU in controls ( $\mathrm{P}=0.012$ ) (Figure 4C). The BDI patients showed a homogeneous pattern of Col III, mRNA expression (mean 18.84 REU) (Figure 4D). Col IV (mean 11.77 REU; Figure 4E) and PAI-1 (mean 22.18 REU, $P=$ 0.001 ; Figure $4 \mathrm{~F}$ ) were also overexpressed in BDI patients.

The Spearman $\left(r_{s}\right)$ correlation showed that the Smad7 mRNA level correlated positively with the level of TGF- $\beta$, Col I, and Col III, mRNA (Table 3). As expected, the mRNA expression of all analyzed genes, except for Col $I V$, correlated significantly with the increase in serum TGF- $\beta$ concentration (data not shown), probably because of the direct influence of TGF- $\beta$ signaling on the expression of ECM proteins.

\section{Discussion}

BDI causes biliary acid flow obstruction, increases bile deposition in hepatic tissue, and causes hepatocyte degeneration, cell death, and release of liver enzymes such as aminotransferases and AP. Additionally, inflammatory

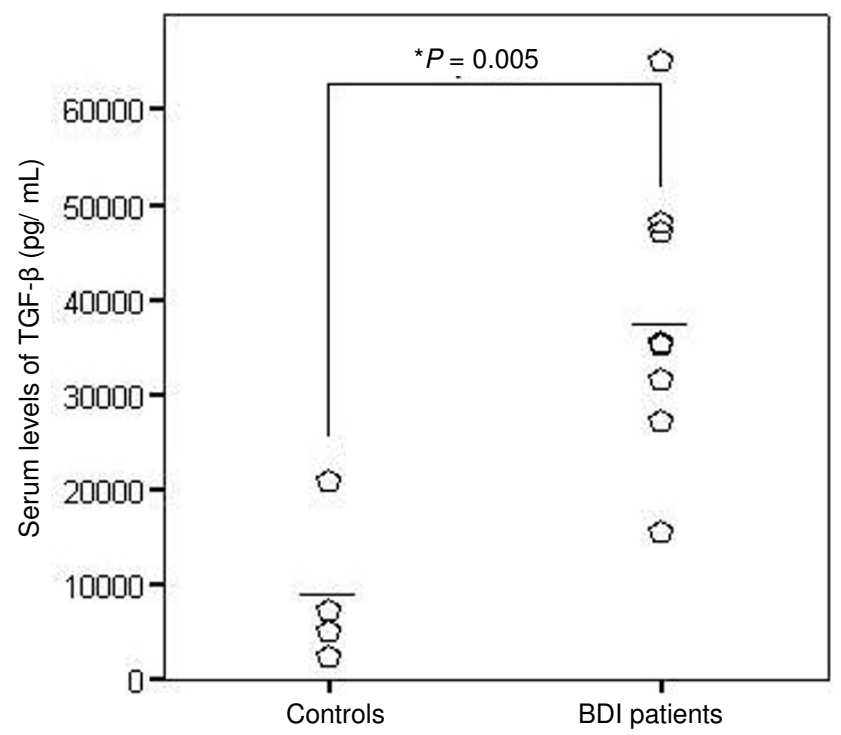

Figure 3

Serum concentrations of TGF- $\beta$ in BDI patients and controls. TGF- $\beta$ concentrations were higher in BDI patients, who had a mean concentration of $39296.36 \mathrm{pg} / \mathrm{ml}$ $(P=0.005$ compared with controls).

cells migrate to the injured tissue, which contributes to secondary biliary cirrhosis $[7,8]$.

TGF- $\beta$ is a pleiotropic molecule involved in ECM proteins expression in fibrogenesis[24,25]. There is some controversy about whether the serum TGF- $\beta$ concentration can be correlated with hepatic injury in different liver diseases[26,27]. Despite this controversy, we found that BDI patients have increased serum concentrations of this protein, perhaps reflecting the overexpression of this cytokine in the liver. mRNA TGF- $\beta$ expression also increases in rat liver cholestasis $[20,28]$.

Dooley et al[20] demonstrated that Smad7 (overexpressed through an adenovirus containing Smad7 cDNA) inhibits TGF- $\beta$ signal transduction and influences the extent of fibrosis when used as preventive therapy in a bile duct ligation (BDL) model of fibrosis. These results suggest that Smad7 is a potential therapeutic tool for liver fibrosis and cirrhosis. The aim of our study was to determine whether $S m a d 7$ expression correlates with the gene expression of TGF- $\beta$, Col I, Col III, Col IV, and PAI- 1 in patients with liver fibrosis caused by BDI.

Tahashi et al[16] showed that Smad7 protein has a critical role in acute and chronic liver injury and that the amount of this protein increases in acute and decreases in chronic liver injury, along with an associated decrease in collagen expression. Our results showing increased Smad7 mRNA 


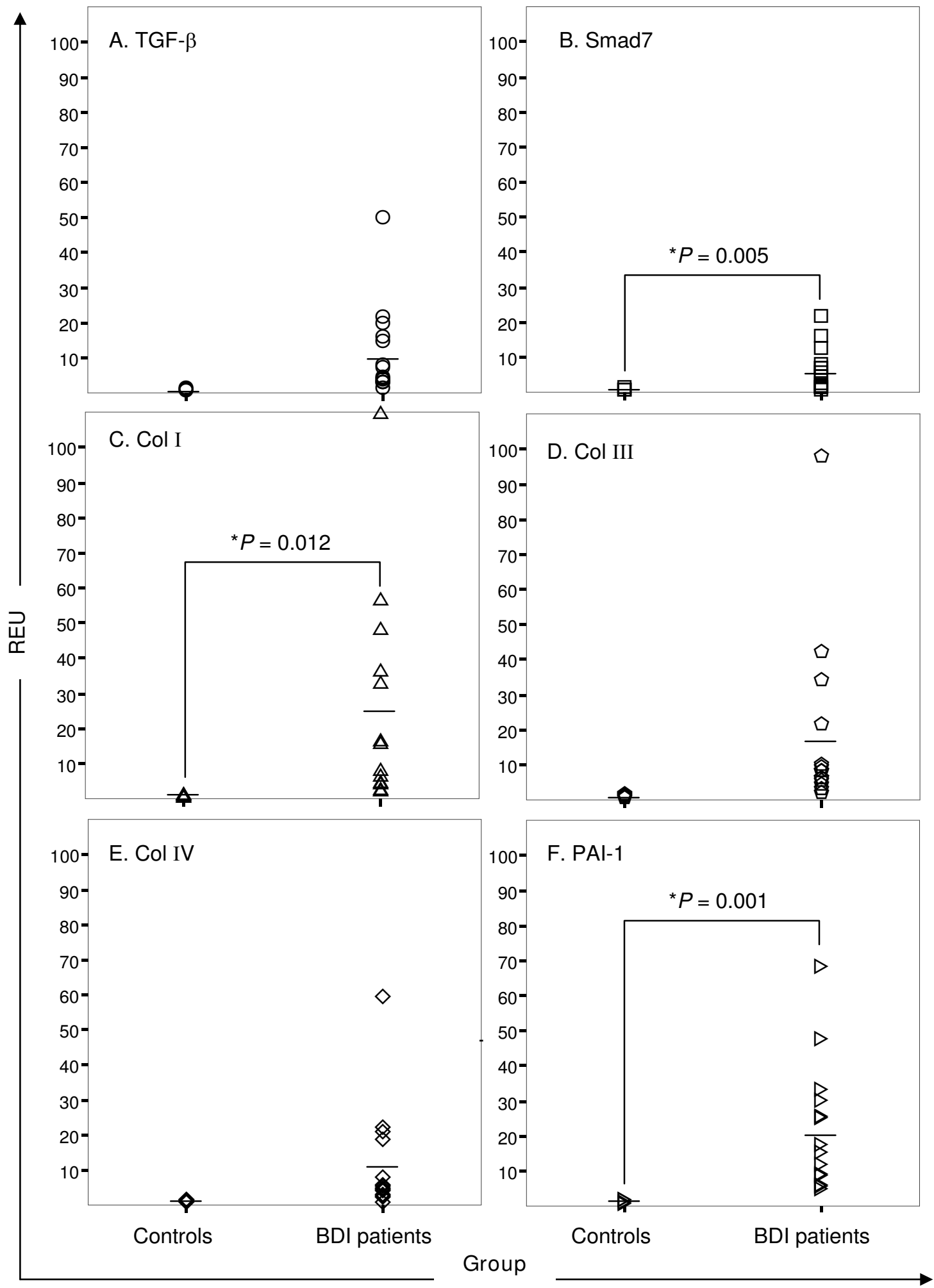

Figure 4

mRNA expression of TGF- $\beta$ and gene targets by real-time PCR. TGF- $\beta$ (A), Smad7 (B), Col II (C), Col III, (D), Col IV $(E)$, and PAI-I (F) mRNA levels were higher in BDI patients than in controls, although the differences were significant only for Smad7, Col I, and PAI-I expression. 
Table 3: Correlation of Smad7 mRNA expression with the expression of TGF- $\beta$, Col I, Col III, Col IV, and PAI-I

\begin{tabular}{lll}
\hline Variable & Spearman correlation $\left(\boldsymbol{r}_{\mathbf{s}}\right)$ & $\boldsymbol{P}$ value \\
\hline TGF- $\beta$ & 0.815 & $* 0.000$ \\
Col I & 0.753 & $* 0.003$ \\
Col III & 0.886 & $* 0.000$ \\
Col IV & 0.209 & 0.474 \\
PAI-I & 0.468 & 0.091
\end{tabular}

$*=P<0.05$

expression along with the collagens I, III and IV seem to contradict those of Tahashi et al. However, they used a $\mathrm{CCl}_{4}$ model that produces damage similar to that caused by alcohol in humans and not a BDL model.

We found that TGF- $\beta$ mRNA expression was 11 -fold higher in BDI patients than in liver donors. This contrasts with a 6-fold higher Smad7 expression level in BDI patients. An increase in the expression of $S m a d 7$ must correlate with a reduction of the expression of fibrogenic molecules because of the direct negative feedback in TGF$\beta$ signaling. Although we found higher Smad7 mRNA expression in patients, expression of the mRNA for collagens and PAI-1 also increased, demonstrating that Smad7 expression is not enough to inhibit TGF- $\beta$ signaling. These results are similar to those reported recently by Seyhan et al[29] who found continuous Smad7 augmentation along with liver fibrosis cholestasis induced in an experimental rat model was insufficient to blunt fibrogenesis. This result may reflect the observation that the transcriptional regulation of ECM proteins can be directed through another TGF- $\beta$ dependent pathway[30], such as connective tissue growth factor (CTGF), a growth factor that is recognized as a fibrogenic molecule in the liver[31,32]. Smad7 expression is regulated by two mechanisms: transcription and protein degradation[33]. The Smad7 transcriptional regulation is mediated by the Ski protein, which inhibits the Smad7 promoter, and the posttransductional regulation is mediated through the effects of Smurf and Jab1 proteins, which promote Smad7 degradation[34,35].

We found a strong positive correlation of Smad7 mRNA expression with TGF- $\beta$, Col I and Col III mRNA expression. The mRNA expression levels were 6.69, 11.59, 26.86, and 18.84 REU, respectively. We also observed a significant amount of fibrotic tissue deposition in the liver biopsies of BDI patients. In the literature, there is one report on increased Smad7 levels in tissue biopsies[36]. In this study, we were limited to analyzing only mRNA expression, and the expression of Smad7 and of ECM proteins need to be measured in BDI patients.
We emphasize that most of the information about the fibrotic process and the molecules involved had been obtained from experimental models (animals and cell cultures). This is the first work in humans to focus on the mRNA expression of ECM proteins and their relationship to Smad7.

The clinical parameters of biliary obstruction evaluated in the patients (AST, ALT, DB, and ALP concentrations) did not correlate with the gene expression levels, serum TGF$\beta$ concentration, or fibrosis percentage. We found no correlation between the lesion type and fibrosis percentage. Type 3 lesion was the most frequent lesion in the patients (11 from 14), but this type was not related to the mRNA expression or liver fibrosis.

Additionally, gene polymorphisms of TGF- $\beta$ (non coding -509 C/T and coding codon 10, codon 25, codon 263) have been associated with modified serum levels of this cytokine in different diseases [37-39]. We showed increased serum levels of TGF- $\beta$ in patients with BDI. In this study, we did not evaluate any of the TGF- $\beta$ polymorphisms. It will be important to plan further studies to determine if serum TGF- $\beta$ levels are more affected by the polymorphisms rather than the presence of bile duct injury.

A recent report demonstrated the predominance of a single nucleotide polymorphism at codon 25 in cirrhotic, but not healthy subjects of Mexican origin[40]. It will also be interesting to determine if there exists a strong relationship between Smad7 and TGF- $\beta$ dependent genes such as collagens, PAI-1, TIMPs, and others that lead to extracellular matrix deposition in patients with different polymorphisms for TGF- $\beta$.

\section{Conclusion}

We found augmented serum concentration of TGF- $\beta$ and an increase in the percentage of fibrotic tissue in the liver of BDI patients. Contrary to expected results, the 6-fold increase in Smad7 expression did not inhibit the expression of TGF- $\beta$, collagens, and PAI-1. We also observed greater expression of Col I and Col III mRNA in BDI patients and significant correlations between their expression and TGF- $\beta$ concentration and Smad7 mRNA expression.

\section{Competing interests}

The authors declare that they have no competing interests.

\section{Authors' contributions}

MPAC performed the experimental work and data analysis, searched the scientific literature, and drafted and edited the manuscript. AMD participated in the design of the project and gave funding support. IYS and OPM par- 
ticipated in the collection of samples. JMHS, SHH, and RAM were responsible for obtaining clinical data from the patients. MVM contributed substantially to the writing of the manuscript, MFM and JSO contributed to the conceptualization of the study, and VDR conceived and designed the study. All authors read and approved the final manuscript.

\section{Acknowledgements}

This work was supported by CONACYT grant 3333I-M to Vidal Delgado Rizo, PhD, and CONACYT grant I380I to Alejandra Miranda Díaz, MD, $\mathrm{PhD}$.

We thank Jesse Haramati for the English translation.

\section{References}

I. Fabre Y, Bueno MR, Rincon-Sanchez AR, Saldana-Cortes J, Vargas R, Armendariz-Borunda J: Mexican infants with extrahepatic biliary atresia display different fibrosis activity. Hepatol Res 2004, 28:79-86.

2. Mercado MA: Lesión en Vías Biliares. México, DF: ETM; 2005.

3. Bachellier P, Nakano H, Weber JC, Lemarque P, Oussoultzoglou E, Candau $C$, Wolf $P$, Jaeck D: Surgical repair after bile duct and vascular injuries during laparoscopic cholecystectomy: when and how? World J Surg 200I, 25(10):1335-1345.

4. Fernandez JA, Robles R, Marin C, Sanchez-Bueno F, Ramirez P, Parrilla $P$ : Laparoscopic iatrogeny of the hepatic hilum as an indication for liver transplantation. Liver Transpl 2004, I0(I): I47-I52.

5. Schmidt SC, Langrehr JM, Raakow R, Klupp J, Steinmuller T, Neuhaus $P$ : Right hepatic lobectomy for recurrent cholangitis after combined bile duct and right hepatic artery injury during laparoscopic cholecystectomy: a report of two cases. Langenbecks Arch Surg 2002, 387(3-4): 183-187.

6. Johnson SR, Koehler A, Pennington LK, Hanto DW: Long-term results of surgical repair of bile duct injuries following laparoscopic cholecystectomy. Surgery 2000, I 28(4):668-677.

7. Rubin E, Gorstein F, Rubin R, Schwarting R, Strayer D: Rubin's Patology: Clinicopatologic Foundations of Medicine. Volume I. Fourth edition. USA: Lippincott Williams and Wilkins; 2005

8. Zakim D, Boyer TD: Hepatology A Textbook of Liver Disease. Volume I. Fourth edition. USA: SAUNDERS; 2003.

9. Delgado-Rizo V, Salazar A, Panduro A, Armendariz-Borunda J: Treatment with anti-transforming growth factor beta antibodies influences an altered pattern of cytokines gene expression in injured rat liver. Biochim Biophys Acta 1998, I 442(I):20-27.

10. Hocevar BA, Brown TL, Howe PH: TGF-beta induces fibronectin synthesis through a c-Jun $\mathbf{N}$-terminal kinase-dependent, Smad4-independent pathway. EMBO J 1999, I 8(5): I345-I356.

II. Inagaki Y, Nemoto T, Nakao A, Dijke P, Kobayashi K, Takehara K, Greenwel P: Interaction between GC box binding factors and Smad proteins modulates cell lineage-specific alpha 2(I) collagen gene transcription. I Biol Chem 200I, 276(19): I6573-16579.

12. Massague J, Wotton D: Transcriptional control by the TGFbeta/Smad signaling system. EMBO J 2000, I 9(8): | 745-I754.

13. Wehrhan F, Rodel F, Grabenbauer GG, Amann K, Bruckl W, Schultze-Mosgau S: Transforming growth factor beta I dependent regulation of Tenascin- $C$ in radiation impaired wound healing. Radiother Oncol 2004, 72(3):297-303.

14. Verrecchia F, Chu ML, Mauviel A: Identification of novel TGFbeta/Smad gene targets in dermal fibroblasts using a combined cDNA microarray/promoter transactivation approach. J Biol Chem 200I, 276(20): I 7058-I 7062.

I5. Derynck R, Zhang YE: Smad-dependent and Smad-independent pathways in TGF-beta family signalling. Nature 2003, 425(6958):577-584.

16. Tahashi Y, Matsuzaki K, Date M, Yoshida K, Furukawa F, Sugano $Y$, Matsushita $M$, Himeno $Y$, Inagaki $Y$, Inoue K: Differential regula- tion of TGF-beta signal in hepatic stellate cells between acute and chronic rat liver injury. Hepatology 2002, 35(I):49-6I. 17. Monteleone G, Pallone F, MacDonald TT: Smad7 in TGF-betamediated negative regulation of gut inflammation. Trends Immunol 2004, 25(10):513-5I7.

18. Nakao A, Fujii M, Matsumura R, Kumano K, Saito Y, Miyazono K, Iwamoto I: Transient gene transfer and expression of Smad7 prevents bleomycin-induced lung fibrosis in mice. J Clin Invest 1999, I04(I):5-II.

19. Takagawa S, Lakos G, Mori Y, Yamamoto T, Nishioka K, Varga J: Sustained activation of fibroblast transforming growth factorbeta/Smad signaling in a murine model of scleroderma. Invest Dermatol 2003, I 2 I ( I):4 I-50.

20. Dooley S, Hamzavi J, Breitkopf K, Wiercinska E, Said HM, Lorenzen J, Ten Dijke $P$, Gressner AM: Smad7 prevents activation of hepatic stellate cells and liver fibrosis in rats. Gastroenterology 2003, I25(I):|78-191.

21. Dong C, Zhu S, Wang T, Yoon W, Li Z, Alvarez RJ, ten Dijke P, White B, Wigley FM, Goldschmidt-Clermont PJ: Deficient Smad7 expression: a putative molecular defect in scleroderma. Proc Natl Acad Sci USA 2002, 99(6):3908-39I3.

22. Song SL, Gong ZJ, Zhang QR, Huang TX: Effects of Chinese traditional compound, JinSanE, on expression of TGF-betal and TGF-betal type II receptor mRNA, Smad3 and Smad7 on experimental hepatic fibrosis in vivo. World J Gastroenterol 2005 , I I ( I 5):2269-2276.

23. Chartrand-Lefebvre $C$, Dufresne MP, Lafortune $M$, Lapointe $R$, Dagenais M, Roy A: latrogenic injury to the bile duct: a working classification for radiologists. Radiology 1994, I 93(2):523-526.

24. Dooley S, Delvoux B, Streckert M, Bonzel L, Stopa M, ten Dijke P, Gressner AM: Transforming growth factor beta signal transduction in hepatic stellate cells via Smad2/3 phosphorylation, a pathway that is abrogated during in vitro progression to myofibroblasts. TGFbeta signal transduction during transdifferentiation of hepatic stellate cells. FEBS Lett 2001 , 502(1-2):4- 10.

25. Friedman SL: Liver fibrosis -- from bench to bedside. J Hepatol 2003, 38(SuppI I):S38-53.

26. Lebensztejn DM, Sobaniec-Lotowska M, Kaczmarski M, Werpachowska I, Sienkiewicz ]: Serum concentration of transforming growth factor (TGF)-beta I does not predict advanced liver fibrosis in children with chronic hepatitis B. Hepatogastroenterology 2004, 5 I (55):229-233.

27. Sakaguchi K, Kitano M, Nishimura M, Senoh T, Ohta T, Terao M, Shinji N, Koide N, Tsuji T: Serum level of transforming growth factor-betal (TGF-betal) and the expression of TGF-beta receptor type II in peripheral blood mononuclear cells in patients with autoimmune hepatitis. Hepatogastroenterology 2004, 5 I (60): I 780-I 783.

28. Biecker E, De Gottardi A, Neef M, Unternahrer M, Schneider V, Ledermann M, Sagesser H, Shaw S, Reichen J: Long-term treatment of bile duct-ligated rats with rapamycin (sirolimus) significantly attenuates liver fibrosis: analysis of the underlying mechanisms. J Pharmacol Exp Ther 2005, 3 I 3(3):952-96I.

29. Seyhan H, Hamzavi J, Wiercinska E, Gressner AM, Mertens PR, KopP J. Horch RE, Breitkopf K, Dooley S: Liver fibrogenesis due to cholestasis is associated with increased Smad7 expression and Smad3 signaling. J Cell Mol Med 2006, I 0(4):922-932.

30. Ihn H, Yamane K, Tamaki K: Increased phosphorylation and activation of mitogen-activated protein kinase p38 in scleroderma fibroblasts. J Invest Dermatol 2005, I 25(2):247-255.

3I. Sedlaczek N, Jia JD, Bauer M, Herbst H, Ruehl M, Hahn EG, Schuppan $D$ : Proliferating bile duct epithelial cells are a major source of connective tissue growth factor in rat biliary fibrosis. $\mathrm{Am}$ Pathol 200I, I 58(4): I239-I 244.

32. Shin JY, Hur W, Wang JS, Jang JW, Kim CW, Bae SH, Jang SK, Yang $\mathrm{SH}$, Sung YC, Kwon OJ, et al.: HCV core protein promotes liver fibrogenesis via up-regulation of CTGF with TGF-betal. Exp Mol Med 2005, 37(2): I 38-145.

33. Park SH: Fine tuning and cross-talking of TGF-beta signal by inhibitory Smads. J Biochem Mol Biol 2005, 38(I):9-I6.

34. Kim BC, Lee HJ, Park SH, Lee SR, Karpova TS, McNally JG, Felici A, Lee DK, Kim Sj: Jab I/CSN5, a component of the COP9 signalosome, regulates transforming growth factor beta signaling by binding to $\mathrm{Smad} 7$ and promoting its degradation. Mol Cell Biol 2004, 24(6):225I-2262. 
35. Zhang S, Fei T, Zhang L, Zhang R, Chen F, Ning $Y$, Han $Y$, Feng $X H$, Meng $A$, Chen YG: Smad7 antagonizes transforming growth factor beta signaling in the nucleus by interfering with functional Smad-DNA complex formation. Mol Cell Biol 2007, 27( I 2):4488-4499.

36. Geng ZM, Zheng JB, Zhang XX, Tao J, Wang L: Role of transforming growth factor-beta signaling pathway in pathogenesis of benign biliary stricture. World J Gastroenterol 2008, I 4(3i):4949-4954.

37. Grainger DJ, Heathcote K, Chiano M, Snieder H, Kemp PR, Metcalfe JC, Carter ND, Spector TD: Genetic control of the circulating concentration of transforming growth factor type betal. Hum Mol Genet 1999, 8(1):93-97.

38. Wang H, Mengsteab S, Tag CG, Gao CF, Hellerbrand C, Lammert F, Gressner AM, Weiskirchen R: Transforming growth factorbetal gene polymorphisms are associated with progression of liver fibrosis in Caucasians with chronic hepatitis C infection. World I Gastroenterol 2005, I I(1 3): 1929-1936.

39. Li X, Yue ZC, Zhang YY, Bai J, Meng XN, Geng JS, Fu SB: Elevated serum level and gene polymorphisms of TGF-betal in gastric cancer. J Clin Lab Anal 2008, 22(3): 164-I7I.

40. Armendariz-Borunda J, Rincon AR, Munoz-Valle JF, Bueno-Topete M, Oregon-Romero E, Islas-Carbajal MC, Medina-Preciado D, GonzalezGarcia I, Bautista CA, Garcia-Rocha S, et al.: Fibrogenic polymorphisms (TGF-beta, PAI-I, AT) in Mexican patients with established liver fibrosis. Potential correlation with pirfenidone treatment. J Investig Med 2008, 56(7):944-953.

\section{Pre-publication history}

The pre-publication history for this paper can be accessed here:

\section{http://www.biomedcentral.com/1471-230X/9/81/pre} pub

\section{Publish with Bio Med Central and every scientist can read your work free of charge}

"BioMed Central will be the most significant development for disseminating the results of biomedical research in our lifetime. "

Sir Paul Nurse, Cancer Research UK

Your research papers will be:

- available free of charge to the entire biomedical community

- peer reviewed and published immediately upon acceptance

- cited in PubMed and archived on PubMed Central

- yours - you keep the copyright 